\title{
Marketing Analysis of Cereal BY-Products used as Livestock Feed in Kano State, Nigeria
}

\author{
S.A. Safiyanu ${ }^{1}$, Z.Y. Abdullahi ${ }^{1}$, I. Suleiman ${ }^{1}$, A. Salihu ${ }^{2^{*}}$ and H. Mohammed ${ }^{3}$ \\ ${ }^{1}$ Department of Agricultural Economics and Extension, Kano State University of Science and \\ Technology Wudil, Nigeria \\ ${ }^{2}$ Department of Agricultural Economics, Institute of Agricultural Sciences, \\ Banaras Hindu University Varanasi, India \\ ${ }^{3}$ Department of Agricultural Economics and Management, Binyaminu Usman Polytechnic, \\ Hadejia, Jigawa State, Nigeria \\ *Corresponding author
}

\begin{tabular}{l} 
Ke y w o r d s \\
$\begin{array}{l}\text { Cereals by- } \\
\text { products, Sorghum } \\
\text { bran and Maize } \\
\text { bran }\end{array}$ \\
\hline Article Info \\
\hline $\begin{array}{l}\text { Accepted: } \\
\text { 04 January } 2018 \\
\text { Available Online: } \\
\text { 10 February } 2019\end{array}$ \\
\hline
\end{tabular}

\section{A B S T R A C T}

The study focused on the profitability analysis of marketing of cereals by-products used as livestock feed in Kano State. Multistage sampling technique was used for the study and data was collected using structured questionnaire supplemented with key informant interview. A total of one hundred and seventy-eight (178) cereals by-product marketers were sampled. The analytical tools employed included descriptive statistics, net marketing margin analysis and marketing efficiency. The result of the socio economic characteristics showed that $12 \%$ of the cereals by-products marketers were adult belonging to the age group of $43-52$ years, $51 \%$ of them had household size of 1-6 members, $43.8 \%$ of the cereals by-products marketers had 14-22 years of marketing experience, $94.9 \%$ married with $88.6 \%$ males, the result of educational background of legumes by-products marketers in the study area shows that $44.9 \%$ had Qur'anic education. The result of the profitability analysis revealed that cereals by-products marketing were profitable as the marketing margin for sorghum bran and maize bran were $\$ 323.34$ and $\$ 470$ respectively. The total revenue realized for the marketing were $\$ 1796.67$ and $\$ 2083.33$ for sorghum bran and maize bran respectively. The result further revealed Gross Margin (GR) of 0.01 and 0.01 for sorghum bran and maize bran traded in the study area while return per naira invested was found to be 1.09 and 1.16 accrued from every $\$ 1.00$ invested for legumes by-products marketing. The result also revealed that marketing of legumes by-products was efficient with $254.17 \%$ and $306.16 \%$ for sorghum bran and maize bran respectively indicating that marketing of these by-products was profitable and efficient in the study area. The study recommended that since cereals by-product marketing is a profitable enterprise more youth should be encouraged to venture into the enterprises this will go a long way in reducing unemployment in the study area. 


\section{Introduction}

Feeds are natural substances which are most commonly organic matter with little components of inorganic matter (Umar, 2002). Livestock feeds are both organic and inorganic substances taken in by animals to provide nutrients such as energy, proteins, minerals and vitamins, metabolized in the body to maintain and produce body tissues, fluids and by-products such as meat, milk and eggs. The feed industry is one of the most competitive businesses in the agricultural sector and is by far the largest purchaser of U.S. corn, feed grains and soybean meal (FAO, 2001).

Studies in various part of Nigeria revealed that about $31 \%$ of the Nigerian land area is cropped and different ranges of livestock feeds are produced (Abubakar, 1998). Livestock feeds are of two types those from cereal (millet bran, sorghum bran and maize bran) and those from legume (cowpea vines, groundnut hay and soybean) (Benerjee, 2005). Marketing provides the mechanism whereby producers exchange their commodity for cash. The cash is used for acquiring goods and services which they do not produce themselves, in order to satisfy a variety of needs ranging from food items, clothing, shelter, medication and schooling to the purchase of breeding stock and other production inputs and supplies (Solomon and Nagussie, 2002). Agricultural marketing from micro view point is the performance of all business activities which direct the forward flow of goods and services to consumers in order to accomplish producer's objectives (Olukosi et al., 2007).

Livestock feed markets suffered from neglect in marketing services in spite of their importance to household welfare and national economy as a whole simply because their full potential is fairly realized. The marketing of industrial and agricultural by-products in
Nigeria is faced with a number of constraints including relatively unorganized market and inadequate feed markets (Powell 1984).

\section{Materials and Methods}

The study was carried out in Kano State, Nigeria. The state lies on latitudes $10^{0} 33^{1} \mathrm{~N}$ to $12^{0} 37^{1} \mathrm{~N}$ and Longitude $7^{0} 40^{1} \mathrm{E}$ to $9^{0} 29^{1} \mathrm{E}$. It is within sudan savannah zone; the total land area of the state is 20,760 square kilometers. The mean daily maximum and minimum temperature are $91.6^{0} \mathrm{~F}\left(33.1^{0}\right)$ and $60.6^{\circ} \mathrm{F}$ $\left(15.85^{\circ} \mathrm{C}\right)$ respectively. Kano state is bordered to the north and northwest by Katsina state, to the east and northeast by Jigawa state, to the south by Bauchi state and to the southwest by Kaduna state. According to the official gazette of Federal Republic of Nigeria (2007), the state had a [population of nine million three hundred and eighty-three thousand six hundred and eighty-two $(9,383,682)$ inhabitants, with an annual growth rate of $3.3 \%$, who are mainly Hausa and Fulani by tribe (NPC, 2006).

Major crops grown in the state includes millet, sorghum, maize, rice, wheat, cotton, gum Arabic and groundnut etc. Their by-products are significant source of food to livestock while rearing of animal like cattle, horses, goats and sheep were more pronounced (RIM, 1992). The state has quite large number of markets. These include rural and urban markets where agricultural commodities are assembled including livestock and their feeds. Most of the market operates weekly or twice a week with the exception of urban markets which operate daily. Kano state is currently made up of forty-four Local Governments Area (LGAs) and the state is agriculturally classified into three (3) zones by the Kano State Agricultural and Rural Development Authority (KNARDA, 1995). Legumes byproducts marketers are found in all the three ADPs zones of Kano state (KNARDA, 2001). 


\section{Sampling method}

A multistage sampling technique was used for data collection in the study area. For this study all the three (3) Zones was considered. The first stage involved purposive selection of two local government areas from each zone based on relative abundance and high intensity of feed marketers. On that basis, Rano and Kura local government areas were chosen from zone I, Danbatta and Shanono local government areas were chosen from zone II and Wudil and Tarauni local government areas were chosen from zone III. The second stage, involved purposive selection of one market from each of the selected local government based on the size, location and high involvement in feed marketing. On that basis, Rano and Kura markets were selected from zone I, Danbatta and Shanono markets were selected from zone II and Wudil and Unguwauku Yan awaki markets were selected from zone III. The third stage, involved random selection of respondents from the six selected markets. A pre-survey was conducted and a total of 595 marketers were identified from all the markets out of which $30 \%$ was considered from each of the selected markets. In the last stage, a total of 178 respondents were randomly selected using flip papers in the study. In each market, the marketers were first identified and a list was prepared, a ballot box method was applied in selecting the marketers.

\section{Analytical tools}

The tools of analysis used for this study are: Descriptive statistics, Marketing margin analysis and Marketing Efficiency.

\section{Marketing margin analysis}

It is the difference in prices of a commodity at different stages of time, place, form and possession as it moves from producer to the ultimate consumer (Olukosi et al., 2007). The model is specified as follows:

Net Marketing Margin (NM)=TR-TMC---(i)

Where:

NMM $=$ Net Marketing margin

TMC = Total Marketing Cost

$\left(\mathrm{C}_{1}+\mathrm{C}_{2}+\mathrm{C}_{3}+\mathrm{C}_{4}+\mathrm{C}_{5}\right)$

Where: $\mathrm{C}_{1}=$ Cost of Transportation $\left(\mathrm{C}_{2}=\right.$ Cost of labor $\left(\mathrm{C}_{3}=\right.$ Marketing charges ( $\mathrm{C}_{4}=$ Storage and $_{5}=$ Commission Fee (N)

\section{Gross ratio}

It is a ratio that measures the overall financial success of a business. A less than 1 ratio is desirable for any business, the lower the ratio the higher the profit (Olukosi and Erhabor, 2008). It is stated as:

$\mathrm{GR}=\frac{\mathrm{TMC}--------(\mathrm{ii})}{\mathrm{TR}}$

Where,

GR $=$ Gross Ratio

TMC $=$ Total Marketing Cost

$\mathrm{TR}=$ Total Revenue

\section{Operating ratio}

It measures the solvency of a business. A ratio less than 1 is desirable because it indicates that the business is making profit. A ratio of 1 implies break-even and a ratio greater than 1 implies a loss (Olukosi and Erhabor, 2008). According to Musa et al., (2006), the lower the ratio $(<1)$ the higher the profitability of the business. It is given as:

$\mathrm{OR}=\frac{\mathrm{TVC}}{\mathrm{TR}}$ -(iii)

Where, 
$\mathrm{OR}=$ Operating Ratio

$\mathrm{TMC}=$ Total Variable Cost

$\mathrm{TR}=$ Total Revenue

\section{Return on capital invested}

Return on capital invested is defined as total income or revenue divided by total marketing cost (Olukosi et al., 2005). It is given as:

$\mathrm{RNI}=\underline{\mathrm{TR}}$

TMC

Where,

RNI = Return on Capital Invested

$\mathrm{TR}=$ Total Revenue

$\mathrm{TMC}=$ Total Marketing Cost

\section{Marketing efficiency}

Marketing efficiency measures the ratio of output to input i.e. the maximization of the ratio of output to input marketing (Olukosi et $a l .$, 2007). The higher the ratio, the higher was the marketing efficiency and vice versa. The formula is specified as:

M.E $=\underline{\text { Value added by marketing X } 100----(v i)}$ Cost of marketing services

Thus:

Value Added by marketing $(\mathrm{VA})=\mathrm{Sp}-\mathrm{Pp}$

Where:

$\mathrm{Sp}=$ Selling price of the commodity (in naira) $\mathrm{Pp}=$ Purchase price of the commodity (in naira)

\section{Results and Discussion}

\section{Socio economic characteristic of respondents}

The study examined the socio-economic characteristics of the respondents' such as age, sex, marital status, household size, educational status, reason for livestock feed marketing, nature of business, years of experience in livestock feed marketing and benefits derived from association. The results are presented in Table 1a shows that the ages of the respondents' ranges from 23-32 years with an average of 44years. The results further revealed that adult of age group of 43-52 years were the highest with $43.1 \%$, while least percentage of $2.3 \%$ goes to age group of 63-72 years. The implication of this finding is that, middle aged take part more in livestock feed marketing than old aged and younger ones in the study area. This tally with the finding force work of Osotimehin (2006) that trader's age affects their efficiency in performing managerial decisions. Household size is one of the socio economic variables that may influence the level of participation in legumes by-product marketing. The result in Table 1a revealed that majority of the livestock feed marketers $51 \%$ had household size of $1-6$ members and $8.5 \%$ goes to household size of 13-30 members. Thus, majority of the respondents in the study area are having less household size because the business is more of middle aged who have less family size than the old ones. Marketing experience is the number of years that the marketers spent in livestock feed business. The longer the experience in the business, the better the performance in livestock feed marketing. The result indicated that most of the respondents $43.75 \%$ had a marketing experience of 14-22 years while $6.25 \%$ of the respondents had marketing experience of 32-49 years. This implies that livestock marketers can manage risk and make sound decision in managing cereal and legume by products used as livestock feed to enhance better performance.

Gender is an important socio-economic parameter which gives the proportion of respondents according either male or female (Ekong, 2003). The study revealed that both male and female were involved in livestock 
feed marketing with male having $88.6 \%$ while female constitute $11.4 \%$ as presented in Table 1b. The few size of female traders participating in livestock feed marketing may be due to religious and cultural barrier in the study area.

It was observed that men generally participate more in production and marketing aspect of agriculture than women who participate more in agro-processing (Ekong, 2003). This agrees with finding of (Ewa and Ago, 1998) who said "economic status and contribution of women is less in developing countries due to continuous dependent on their male counterparts and the social setting of their society. Education is very important in every aspect of life and it plays a fundamental role towards agricultural development, it enhances easy assimilation, awareness and receptivity to innovations of agricultural practices. Thus, education gives a better awareness, persuasion and adoption of innovation hence better improvement in production and marketing (Adams, 1992). The result in Table 1b indicated that $44.9 \%$ of legume by-products marketers had Qur'anic education while 1.1\% had tertiary education having the least percentage. This may be due to the nature of the enterprise which is dominated by people from rural areas.

Table.1a Socio Economic characteristics of cereal by-products marketers

\begin{tabular}{|l|l|l|l|}
\hline Variables & Frequency & Percentage & \\
\hline Age & 3 & & \\
\hline $\mathbf{2 3 - 3 2}$ & 60 & 34.7 & \\
\hline $\mathbf{4 3 - 5 2}$ & 77 & 43.1 & \\
\hline $\mathbf{5 3 - 6 2}$ & 32 & 18.2 & \\
\hline $\mathbf{6 3 - 7 2}$ & 4 & 2.3 & \\
\hline Total & $\mathbf{1 7 6}$ & $\mathbf{1 0 0}$ & \\
\hline Mean 44.35 & Min 23 & Max 68 & SD 7.793 \\
\hline Household size & & & \\
\hline $\mathbf{1 - 6}$ & 89 & 50.6 & \\
\hline $\mathbf{7 - 1 2}$ & 72 & 40.9 & \\
\hline $\mathbf{1 3 - 1 8}$ & 12 & 6.8 & \\
\hline $\mathbf{1 9 - 2 4}$ & 2 & 1.13 & \\
\hline $\mathbf{2 5 - 3 0}$ & 1 & 0.57 & \\
\hline Total & $\mathbf{1 7 6}$ & $\mathbf{1 0 0}$ & \\
\hline Mean 7.3 & Min 1 & Max 29 & SD 4.112 \\
\hline Marketing experience & & & \\
\hline $\mathbf{5 - 1 3}$ & 69 & 39.20 & \\
\hline $\mathbf{1 4 - 2 2}$ & 77 & 43.75 & \\
\hline $\mathbf{2 3 - 3 1}$ & 19 & 10.8 & \\
\hline $\mathbf{3 2 - 4 0}$ & 9 & 5.11 & \\
\hline $\mathbf{4 1 - 4 9}$ & 2 & 1.14 & \\
\hline Total & $\mathbf{1 7 6}$ & $\mathbf{1 0 0}$ & \\
\hline Mean 17.64 & Min 5 & Max 45 & SD 7.62 \\
\hline & Source: field survey, 2013 & \\
\hline
\end{tabular}


Table.1b Socio economic characteristics of cereal by-products marketers

\begin{tabular}{|l|l|l|}
\hline Variables & Frequency & Percentage \\
\hline Gender & 156 & 88.6 \\
\hline Male & 20 & 11.4 \\
\hline Female & $\mathbf{1 7 6}$ & $\mathbf{1 0 0}$ \\
\hline Total & & \\
\hline Level of education & 32 & 18.2 \\
\hline Primary & 60 & 34.1 \\
\hline Secondary & 79 & 44.9 \\
\hline Quranic & 3 & 1.7 \\
\hline Adult & 2 & 1.1 \\
\hline Tertiary & $\mathbf{1 7 6}$ & $\mathbf{1 0 0}$ \\
\hline Total & & \\
\hline Marital status & 166 & 94.9 \\
\hline Married & 3 & 1.7 \\
\hline Single & 3 & 1.7 \\
\hline Divorced & 3 & 1.7 \\
\hline Widow & $\mathbf{1 7 6}$ & $\mathbf{1 0 0}$ \\
\hline Total & & \\
\hline $\begin{array}{l}\text { Association } \\
\text { Membership }\end{array}$ & 33 & 18.8 \\
\hline Member & 143 & 81.2 \\
\hline None member & $\mathbf{1 7 6}$ & $\mathbf{1 0 0}$ \\
\hline Total & & \\
\hline $\begin{array}{l}\text { Benefits } \\
\text { association }\end{array}$ & $\mathbf{3 1}$ & $\mathbf{1 0 0}$ \\
\hline Helping one another & 14 & \\
\hline Source of information & 10 & \\
\hline Source of credit & 7 & \\
\hline Total & & \\
\hline for & & \\
\hline
\end{tabular}


Table.2 Profitability analysis per $114 \mathrm{~kg}$ of sorghum bran and $116 \mathrm{~kg}$ of maize bran used as livestock feed

\begin{tabular}{|l|l|l|l|l|}
\hline & Sorghum bran & & Maize bran & \\
\hline Parameters & Value ( /kg) & $\%$ TMC & Value (\#/kg) & $\%$ TMC \\
\hline Marketing Cost (MC) & & & & \\
\hline Purchase price & 3683.33 & 93.05 & 1613.33 & 89.46 \\
\hline Transportation cost & 125 & 3.16 & 50 & 2.77 \\
\hline Storage cost & 50 & 1.26 & 30 & 1.66 \\
\hline Cost of labour & 80 & 2.02 & 90 & 4.99 \\
\hline Marketing charges & 20 & 0.51 & 20 & 1.11 \\
\hline Total Marketing Cost & 3958.33 & 100 & 190 & 100 \\
\hline Total Revenue & 4375 & & 2083.33 & \\
\hline Gross Ratio & 0.01 & & 0.01 & \\
\hline Operating Ratio & 0.90 & & 0.87 & \\
\hline Marketing Margin & 416.67 & & 280 & \\
\hline Net Marketing Margin & & & 1893.33 & \\
\hline RNI & 1.10 & & 1.16 & \\
\hline Marketing Efficiency $(\%)$ & 168.61 & & 306.16 & \\
\hline
\end{tabular}

Source: Field Survey, 2013

The finding of this study tally with (Bivan, 1995) who reported that education attendant is paramount in respondent's decision making. The result in Table $1 \mathrm{~b}$ further revealed that majority of the livestock feed marketers $81.2 \%$ were membership to an association while $18.8 \%$ of the traders were no having membership to an association. The result also reveals that $45.2 \%$ of the members benefited from the association in helping one another, $32.3 \%$ benefited with source of information while $22.6 \%$ benefited with credit. Imoudu and Afolabi (2002) posited that the market structure for agricultural products in Nigeria is not perfectly competitive due to the collusive tendencies of sellers by forming associations for particular products.
Profitability of marketing cereal byproducts used as livestock feed

The profitability measures such as the marketing margin, net marketing margin (NMM), marketing revenue and return to naira invested (RNI), gross ratio (GR) and operating ratio (OR) were determined and presented in Table 2. The results revealed that the total sales per year of Sorghum brand and Maize brand were $\$ 332,383.98$ and $\$ 385,416.08$ respectively. The return to naira investments of 1.09 and 1.16 for Sorghum brand and Maize brand implies that a profit of $\$ 0.09$ and $\$ 1.16$ would return to the invested respectively. The result further revealed gross ratio (GR) of 0.01 and 0.02 for Sorghum brand and Maize brand traded. The ratios were all less than unity. A less than 1 ratio is 
preferable for any farm business, Olukosi and Erhabor, (2008) posited that the lower the ratio the high the profit impliedly, Sorghum brand and Maize brand were profitable in the study area. In similar vein, the operating ratio (OR) of Sorghum brand and Maize brand were obtained as 0.91 and 0.87 respectively. Operating ratio of both commodities was lower than unity. Olukosi and Erhabor, (2008) also reported that a ratio less than one indicates that the marketers are marking profit.

The results in Table 2 show the marketing efficiencies of Sorghum brand and Maize brand used as livestock feed was found to be $254.17 \%$ and $306.16 \%$ respectively. The result further revealed that Maize brand has the highest marketing efficiency as compared to Sorghum brand in the marketing of cereals by-products in the study area. The higher the ratio the higher the marketing efficiency and vice versa (Olukosi, et. al., 2007).

In conclusion, the prospect of cereal byproducts marketing in Kano state were found to be full time occupation providing employment for a large number of individuals. This could be attributed to the amount of profits realized in both activities. The socio economic characteristics that enhance higher marketing of cereal byproducts marketers were age, household size, years of experience and level of income.

\section{Recommendation}

Based on the findings of the study the following recommendations were made:

i. Cereal by-products marketers should form strong and viable corporative groups which will make them have access to institutional support.

ii. Since cereal by-products marketing is a profitable enterprise more youth should be encouraged to venture in to the enterprises this will go a long way in reducing unemployment in the study area.

iii. There is need for government and its development partners to encourage people to go into farming so that there will be an increase in the quantity of cereals which subsequently lead to an increase in the availability of livestock feeds.

\section{References}

Abubakar, M.M. (1998) "Utilization of Unconventional Feedstuffs for Sustainable Livestock Production" Inaugural Lecture Series No. 09. Delivered at the Abubakar Tafawa Balewa University, Bauchi State, Nigeria on $30^{\text {th }}$ March, 1998.

Adedoyin, A.J. and Dittoh, J.S. (1997). Essential of Agricultural Economics, Centre for Agricultural Development (CERD), Ibadan, Nigeria. Pp. 48-50.

Benerjee, G C. (2005). Animal Husbandry Eight Edition. Oxford and IBH Publishing Co. Pvt. Ltd. New Delhi, pp 657-659.

Central Bank of Nigeria (1999): CBN Annual Report of 1998, Lagos Nigeria, Vol.10 page 41.

Federal Republic of Nigeria, (2007). Official Gazette. No24 Volume 94 Published by the Federal Government Printer, Lagos, Nigeria.

Food and Agricultural Organisation (2001).

FAO Production Year Book: FAOSTAT, Volume 49, No. 130. pp 39-41.

Kano State Agricultural and Rural Development Authority (KNARDA) Headquarters, Kano, 1995. Bulletin, Kano, Nigeria. Pp 1-5

Kano State Agricultural and Rural Development Authority (KNARDA) Headquarters, Kano 2001 Bulletin. Pp 11-19. 
Lakpini, C.A.M. (2002). Feed and Feeding Strategies for Small Ruminant in various Stages NAPRI, Shika, Zaria, Nigeria. Pp 40 - 46.

National Population Commission (2006), Census Report. Pp 30-35.

Olukosi, J.O. (2007). Introduction to Agricultural marketing and Prices: Principles and Application. $3^{\text {rd }}$ Edition Living Books Series G. U. Publishers, Abuja, Nigeria.

Olukosi, J.O. Isitor, S.U. and Moses, O.O. (2005). Introduction to Agricultural Marketing and prices: Living Books Series G. U. Publishers, Abuja, Nigeria. Pp. 46-47.

RIM, (1992). Nigerian National Livestock
Resource Survey. (Vol. IV) Report by Resource Inventory and Management Limited (RIM) to FDL and PCS, Abuja, Nigeria. Retrieved from http:/www.fao.org/wairdocs/ILRI/*55 48E/*5548e09.htm\#TopOfpage.

October, 2012.

Umar, A.N. (2002). The Voluntary Intake and Digestibility Combinations of Crop Residues and Legume Hay for Sheep.

Umar, M.I. (2007). By-product of Cereals and Pulses used as Livestock Feed in Kano Metropolis. An Unpublished B.Sc. Agricultural Project Submitted to the Department of Animal Science, Kano University of Science and Technology, Wudil. Pp. 30.

\section{How to cite this article:}

Safiyanu, S.A., Z.Y. Abdullahi, I. Suleiman, A. Salihu and Mohammed, H. 2019. Marketing Analysis of Cereal BY-Products used as Livestock Feed in Kano State, Nigeria. Int.J.Curr.Microbiol.App.Sci. 8(02): 20-28. doi: https://doi.org/10.20546/ijcmas.2019.802.005 